\title{
VÁRI VINCE
}

\section{A rendőrség hatékonyságmérése \\ a nemzetközi szakirodalomban - különös tekintettel a bizalom és a legitim müködés jelentőségére}

\begin{abstract}
A társadalmi bizalom, mint egyfajta töke, lényegét tekintve nem más, mint a rendőri működés „társadalmi hatásainak” kollektív érzülete. Kollektív érzület és egyben viszonyulás a hatalom erőszakszervezetéhez. Akceptálása egyben a regnáló hatalom elfogadása is, gondolván arra, hogy a rendőrség a hatalom gyakorlásának erőszakgyakorló jellegénél fogva „ultima ratio” eszköze, amely, más közhatalmi szervezetektől eltérően, az erőszakkal történő kikényszerítés teljes eszköztárával bír. Így a hozzá való társadalmi viszonyulás emblematikusan az állampolgár hatalomhoz való viszonyulásának leképeződése is, amit a társadalmi, gazdasági és politikai kontextus változásával együtt érdemes szemlélni és értékelni. Mivel a rendőrség az állami büntetőhatalom érvényesítésének egyik intézményesülése, a büntető igazságszolgáltatási tevékenység politikai és jogi kereteinek minősége szükségképpen árnyalja a rendőrségről alkotott képet. Különös jelentőségü ez a szempont a tág értelemben vett büntetőjog rekodifikációs időszaka utáni években, hiszen a rendőrség tevékenységének bárminemű átszervezése feltételezi a büntető igazságszolgáltatási rendszer megújult eleminek figyelembevételét. ${ }^{1}$
\end{abstract}

\section{A rendőrség múködését kísérō lakossági bizalom}

Az Egyesült Államokban már jó pár évtizede folynak kutatások a témában. Számos tanulmányban megerősítették, hogy a közösség bizalma a rendőrségben elsődlegesen a demográfiai, attitűdbeli, és a környezeti tényezők függvénye. Más kutatások szintén arra a következtetésre jutottak, hogy az országok közötti eltérések is megmagyarázhatók bizonyos szempontrendszer alapján.

1 Amberg Erzsébet: Büntetőjogi változások-rendészeti reakciók. In: Gaál Gyula - Hautzinger Zoltán (szerk.): Tanulmányok a „Biztonsági kockázatok - rendészeti válaszok” című tudományos konferenciáról. Pécs, 2014, 121. o. 
Kínai szerzők tanulmánya ${ }^{2}$ több ilyen elörejelző szempont alapján vizsgálta a közbizalom alakulását. Az egyik, ami országos szintü jelző, az emberölések és a demokrácia értékeinek legitimitása és társadalmi intézményesülése volt. Másik egyéni szintű előrejelző ugyancsak a lakosság bizalmát célozva, adatsorokat gyüjtött három rendőrségi nemzetközi felmérésből. Hierarchikus általánosított lineáris modellezéssel a multinomiális függő változókat alapul véve szignifikáns és negatív kapcsolatot találtak az emberölési ráta és a lakosság bizalma között. Az emberek azokban az országokban, ahol magasabb az emberölési ráta, kevésbé bíznak a rendőrségben. A demokrácia intézményeit elemezve úgy találták, hogy önmagában pozitívan kapcsolódik hozzá a közbizalom. Az egyéni szintủ változók - mint az életkor és iskolai végzettség - alapján is találták szignifikáns prediktorokat. Pozitív összefüggést fedeztek fel a konzervatív értékrend, továbbá a személyes elégedettség és a rendőrségbe vetett bizalom között. Összhangban az attitüdbeli, illetve a társadalmi kontextus jelzőkkel általában a deviáns szubkultúrákban lehet alacsonyabb szintü rendőrség iránti bizalommal számolni. Másrészt, azok, akik elégedettebbek voltak az országuk demokratikus fejlődésével, kedvezőbben viszonyultak a rendőrséghez. Vizsgálataik során arra jutottak, hogy a rendörség teljesítményében nagyobb erőfeszítéseket kell tenni a büncselekmények csökkentése érdekében, de közben védeniük kell a társadalom alapvető demokratikus értékeit.

A kutatók a rendőrségbe vetett bizalmat a korábbi vizsgálatok alapján elsősorban egyéni szintű tényezőkkel vizsgálták, úgymint a demográfiai és szemléletbeli változók, de az országos szintü változók hatását már nagyrészt figyelmen kívül hagyták. Míg a korábbi vizsgálatok feltárták a kapcsolatot a bünözés és a rendőrség iránti bizalom között egy adott országon belül ${ }^{3}$, vagy egy városban ${ }^{4}$, ez a tanulmány megerősítette ezt a kapcsolatot nemzetközi vo-

2 Hyunseok Jang - Hee-Jong Joo - Jihong Zhao: Determinants of public confidence in police: an international perspective. Journal of Criminal Justice, vol. 38, 2010, pp. 57-68.

3 Yolander G. Hurst - James Frank - Sandra Lee Browning: The attitudes of juveniles toward the police: A comparison of black and white youth. Policing: An International Journal of Police Strategies \& Management, vol. 23, iss. 1, 2000, pp. 37-53.; Brian K. Payne - Randy R. Gainey: Attitudes about the police and neighborhood safety in disadvantaged neighborhoods: the influence of criminal victimization and perceptions of a drug problem. Criminal Justice Review, vol. 32, 2007, pp. 142-155.; Jan Van Dijk: Attitudes of victims and repeat victims toward the police: Results of the International Crime Victims Survey. In: Graham Farrell - Ken Pease (eds.): Repeat victimization: Crime prevention studies, vol. 12. Criminal Justice Press, New York, 2001, pp. 27-52.; Ronald Weitzer - Steven A. Tuch: Determinants of public satisfaction with the police. Police Quarterly, vol. 8, 2005, pp. 279-297.

4 Michael D. Reisig - Roger B. Parks: Experience, quality of life, and neighborhood context: A hierarchical analysis of satisfaction with police. Justice Quarterly, vol. 17, 2000, pp. 607-629. 
natkozásban is. Az országos szintű változók közül a demokratikus értékek kapcsán azt is megállapították, hogy pozitívan kapcsolódik hozzá a rendörség iránti társadalmi bizalom, bár ennek a hatása nem volt olyan erős, mint az emberölések számának alakulása. Továbbá, ez a kutatás azt is vizsgálta, hogy az egyéni szintü tényezőknek (mint például a demográfiai és szemléleti változóknak) milyen befolyásuk van a rendőrség iránti bizalomra. Ilyen jelentős demográfiai változók voltak: az életkor, a nem, a képzettség. Hasonlóan a korábbi kutatások eredményeihez, amelyek országon belüli adatokat használtak, ez a nemzetközi tanulmány megállapította, hogy általában az idősebb emberek mutatnak kedvezőbb attitüdöt a rendőrség irányába ${ }^{5}$. Továbbá az iskolázottabb emberek ritkábban jelentenek kedvező attitüdöt a rendőrség irányába ${ }^{6}$. Ez a vegyes kapcsolat az iskolázottság és a rendőrség iránti bizalom között egybevág az országon belüli adatokkal. Ezen kívül a nők marginálisan magasabb szintü bizalmat mutattak az országos szintủ változók alapján. Összegezve tehát, a kutatás szerint a politikai irányultság és az élettel való általános elégedettség jelentősen és kedvezően befolyásolta az egyén rendőrség iránti bizalmát. Azaz a nagyon elégedett, és a politikailag konzervatív egyének nagyon magas szintü bizalomról tettek tanúbizonyságot. Más szemléletbeli változók, mint a társadalmi devianciák (hajléktalanok, melegek, külföldiek) elfogadási hajlama, a politikai konfliktusok megítélése, és általában a demokrácia intézményeinek müködésével való elégedettség, következetesen szignifikánsan hatnak a bizalomra. A deviáns szubkultúrák vagy a másság nagyobb elfogadása alacsonyabb szintü bizalmat feltételez a rendörség irányába, emellett a liberális beállítottság az autoritás és az etatista felfogás elutasítását is hordozza. Ami a politikai rendszeren belüli konfliktusok megítélését illeti, mint azt már korábbi tanulmányok is feltárták ${ }^{7}$, azok az emberek, akik úgy vélték, hogy az országot kevés gazdag ember irányítja, kimu-

\footnotetext{
5 Steven G. Brandl et al.: Global and specific attitudes toward the police: Disentangling the relationship. Justice Quarterly, vol. 11, 1994, pp. 119-134.; Liqun Cao et al.: Public attitudes toward the police: A comparative study between Japan and America. Journal of Criminal Justice, vol. 26, 1998, pp. 279289.; Yolander G. Hurst - James Frank: How kids view cops: The nature of juvenile attitudes toward the police. Journal of Criminal Justice, vol. 28, 2000, pp. 189-203.; Ronald Weitzer - Steve A. Tuch: Perceptions of racial profiling: Race, class, and personal experience. Criminology, vol. 40, 2002, pp. 435-457.

6 Richard Scaglion - Richard G. Condon: Determinants of attitudes toward city police. Criminology, vol. 17, 1980, pp. 485-494.

7 Thomas B. Priest - Deborah B. Carter: Evaluations of police performance in an African American sample. Journal of Criminal Justice, vol. 27, 1999, pp. 457-465.; Richard Quinney: Class, state and crime: On the theory and practice of criminal justice. New York, 1977; Henry D. et al.: Theoretical criminology. 4th ed. Oxford University Press, New York, 1998
} 
tathatóan alacsonyabb szinten bíztak a rendőrségben. Végezetül, az emberek, akik elégedettek voltak az ország demokratikus fejlődésével és intézményei müködésével, szintén jobban bíztak a rendőrségben. Ez volt az egyetlen független változó, amely a legerősebb befolyást gyakorolta a rendőrség iránti bizalomra. Ez az eredmény megerősíti a szerzők feltevését, hogy jelentős a kapcsolat a demokratikus intézményekkel való elégedettség és a rendőrség iránti bizalom között.

Amint látszik, az előbbiekben részletezett kutatás is megerősítette a szignifikáns kapcsolatot a bünözés mértéke és a rendőrség iránti bizalom kontextusában. Ebből is következik, hogy a rendőrségi szervezeteknek úgy kell nagyobb erőfeszítéseket tenniük az erőszakos büncselekmények csökkentésére, hogy közben védelmezik a demokratikus értékeket is. Annak érdekében, hogy a rendőrségben bízni tudjanak az állampolgárok, a rendőrségnek fenn kell tartania és demonstrálnia kell a politikai semlegességét és a demokratikus értékek melletti feltétlen elkötelezettségét, a polgárok tudomására hozva, hogy ők a teljes népességet képviselik, és nem csak azt a hatalmat, amely éppen irányítja a tevékenységüket.

Ugyancsak a rendőrség iránti bizalmat vette célba tanulmányában Stanko és Bradford ${ }^{8}$. Ezúttal a Metropolitan Police Service modellje alapján fejlesztettek ki négy, a közbizalmat meghatározó tényezőt:

- képes-e a rendőrség teljesíteni alapvető feladatát (eredményesség, nemcsak a bünözés ellen harcol, hanem látható a jelenléte, továbbá biztosítja a rendőri nyilvános eseményeket, illetőleg válaszol vészhelyzet esetén);

- a rendőrök által tanúsított tisztességes bánásmód, a szükségesség és az arányosság betartása függetlenül attól, hogy mennyire segítőkészek vagy barátságosak a rendőrrel (tisztességes eljárások, bánásmód);

- milyen mértékben veszik figyelembe a közösség igényeit (közösségi elkötelezettség);

- tud-e, képes-e reagálni a rendőrség a helyi közösség problémáira és a helyi közösség közbiztonságát érintő sajátos negatív helyzetre (zavar).

8 Elizabeth A. Stanko - Ben Bradford: Beyond measuring 'how good a job' police are doing: The MPS model of confidence in policing. Policing: A Journal of Policy and Practice, vol. 3, no. 4, 2009, pp. 322-330. 


\section{A rendőrség legitim múködése és a lakossági bizalom közötti összefüggés}

Bár a legitimitás és a bizalom leginkább csak a szervezet tevékenységét kísérő, egyfajta „utóhatásnak" tekinthető, jelentős hatással van a közbiztonság fenntartásával kapcsolatos rendészeti tevékenység minőségére is. A legitim rendőri müködés ebben a kontextusban nem csupán a vonatkozó jogszabályok és normák betartását jelenti a rendőri tevékenység (intézkedések, eljárások) ellátása során, hanem az állampolgárokkal való fair, tisztességes, méltányos és korrekt bánásmódot és viselkedési formát egyaránt. Utóbbi magában foglalja a részrehajlásmentes és egyenlö bánásmódot mindenkivel, aki bármilyen minőségben és formában kapcsolatba kerül a rendőrséggel. A legitim módon végzett rendőri munka során válik igazán hangsúlyossá, hogy ténylegesen ez vezet ahhoz, hogy a lakosság rendőrség iránti attitüdje pozitívvá váljon, és a többség aktívan is támogassa a rendőrség munkáját. Ily módon a rendőrség valóban hatékonyan és a közösség biztonságának érdekében széles társadalmi felhatalmazottsággal töltheti be rendfenntartó szerepét ${ }^{9}$.

Természetesen a rendőrök nem csupán „egy” bizonyos szerepet töltenek be egy modern, pluralista társadalomban, ezért hiba lenne öket kizárólag egy nézőpontból szemlélni. Ebböl is következik, hogy a megítélésükkel kapcsolatosan sem lehet általánosítani és egységes elvárást támasztani a közvélemény irányába. Kézenfekvő, hogy más lesz a véleménye annak, aki a segélyhívása után gyors és hatékony rendőri intézkedésnek volt részese, mint annak, aki nemrég kapott egy közigazgatási bírságot, miután óránkénti három kilométerrel túllépte a megengedett legnagyobb sebességet. A hangsúly nem az aktuális vélekedésen vagy a formális ítéletalkotáson van. Jelentős kutatások is megerősítették a hipotézist, hogy még a negatív aktusok is elfogadtathatók (letartóztatások, büntetések stb.), ha átláthatóvá és kézzelfoghatóvá teszik az eredményhez vezető döntési folyamatokat. Az ugyanis megismerhetővé és leginkább megérthetővé válik bárki számára. Ha a közösség számára átláthatók a folyamatok és azok tisztessége, törvényessége és pártatlansága, akkor nagyobb valószínűséggel kerül sor a negatív eredmények elfogadására. A procedurális vagy eljárási igazság megléte a következő főbb kritériumokon nyugszik: 9 Kristina Murphy - Lyn Hinds - Jenny Fleming: Encouraging Public Cooperation and Support for
Police. Policing \& Society, vol. 18, no. 2, 2008, pp. 136-155. 
- egyrészt az egyének kapjanak lehetőséget a rendőrség velük kapcsolatos döntéseinek értelmezésére azzal, hogy teljes és alapos tájékoztatást kapnak, és ha szükséges, magyarázatot a kérdéseikre;

- az eljárás során tiszteletben tartják a méltóságukat, emellett pártatlan és részrehajlásmentes hozzáállást tapasztalnak;

- az egyének megbíznak abban, hogy a döntéshozókat és azok végrehajtóit neutrális célok mozgatják ${ }^{10}$.

A procedurális igazság esszenciálisan minden rendőri aktus velejárója, dinamikus együtthatóként a legitimitás és a bizalom formálója és a rendőrséggel való közösségi elégedettség elemi determináló tényezője. A legitimitás és a bizalom felépíthető, ha a rendőr és állampolgár mindennapi interakcióit ez a szellemiség mozgatja, amennyiben ezek a vonások nem jellemzik, az könynyen és gyorsan leépülhet. Úttörőként Michael Lipsky azonosította ezt a dinamikus kölcsönhatást számos közszolgálati foglalkozás körében, így nemcsak a rendőr, hanem az ügyész, a bíró és a szociális munkás esetében is ${ }^{11}$. A bizalom kérdésköre felértékelődik a jelenlegi globalizálódó világban, és szervesen kapcsolódik a rendőrségi stratégiák harmadik állomásához. Kelling és Moore a rendörség történetében három korszakot különböztetett meg: a politikai, a reform, és a közösségi problémamegoldás korszakait ${ }^{12} .2001$ óta beszélhetünk a terrorizmusveszély megelözése miatti negyedik állomásról ${ }^{13}$.

Kétségtelen, hogy az utóbbi évtizedekben a rendőrséggel kapcsolatos elvárások jelentősen átrendeződtek, ahogy a rendőrségi stratégiák is más utakon haladnak. A kilencvenes években népszerüvé váló, a közösség tagjaival szoros kapcsolatot ápolni kívánó közösségi rendőrségi modell éppúgy a közvélemény bizalmának megerősítésére összpontosított, mint a 2000-es évek végén megjelenő bizalomépítő rendőrségi modell. Azonban a közösségi rendőrségi modell már nem volt képes kezelni a 2000-es évek terrorveszélyével és a fokozódó társadalmi egyenlőtlenségek miatt kialakuló feszültségek-

\footnotetext{
10 Lorraine Mazerolle - Emma Antrobus - Sarah Bennett - Tom R. Tyler: Shaping Citizen Perceptions of Police Legitimacy: A Randomized Field Trial of Procedural Justice. Criminology, vol. 51, no. 1, 2013, pp. 33-63.

11 Michael Lipsky: Street-Level Bureaucracy: Dilemmas of the Individual in Public Services, 30th anniversary expanded edition, Russel Sage Foundation, New York, 2010

12 George L. Kelling - Mark H. Moore: The Evolving Strategy of Policing. Perspectives on Policing, National Institute of Justice-John F. Kennedy School of Government, Harvard University, 1988

13 Willard M. Oliver: The Fourth Era of Policing: Homeland Security, International Review of Law, Computers \& Technology, vol. 20, nos. 1-2, 2006, pp. 49-62.
} 
kel összefüggésben megnövekedett bünözési félelmet. Noha a modellnek csupán a bünözés mértékére gyakorolt hatása nem volt kimutatható, addig a társadalmi bizalom erősödését számos kutatás igazolta. ${ }^{14}$ Ennek következtében a kezdeti közösségi rendőrségi modell a problémaorientált bünözéskontroll irányába tolódott ${ }^{15}$, majd az információs társadalom igényeit kielégítő intelligencie led policing ${ }^{16}$ a célirányosan megszerzett és adekvát adatok intenzív és gyors felhasználást célozza viszonylag szük bünözési frekventumokban, azaz „hot spot”-okban ${ }^{17}$.

Az egyes rendőrségi stratégiák fejlődése közben átértékelődött a rendőrségi kommunikáció jelentősége is. Aminek legfőbb célja kell hogy legyen, hogy a döntéshozatali folyamatok transzparenciájának megteremtésével demonstrálja az eredmények semleges, tisztességes és politikai indokoktól mentes létrejöttét. Egyértelmüen és félreérthetetlenül kifejezésre kell jutnia, hogy mi zajlik a társadalom és a rendőrség kollektív interakciójában, ami a közvélemény formálásában szerepet játszhat. Ahogy a rendőrségi intézkedésekhez kapcsolódó lakossági percepciók sem homogének, a lakosság egyes csoportjaiban sem ugyanolyan hatások érvényesüléséről beszélhetünk. Az egyik jelentős kutatás megmutatta, hogy számos faktor befolyásolja a rendörség lakossági megítélését, egyebek között a saját, a baráti és rokoni körben elöforduló büncselekményekkel kapcsolatos negatív tapasztalatok, beleértve a média rendőrségi visszaélésekkel kapcsolatos hírközléseit. Ezek a tényezők negatív hatások tekintetében eltérően jelentkeztek az egyes etnikai és faji csoportok esetében ${ }^{18}$.

Mindenekelött a legfontosabb annak eldöntése, hogy mit is kell megjeleníteni a nyilvánosság előtt a rendőrség semlegessége, pártatlansága és céljai kapcsán, ami meggyőzővé és megmagyarázhatóvá teszi a döntéseit, és feladatvégzése eredményeit. A nyilvánosság meggyőzését jellemzően az eljárá-

14 Charlotte Gill - David Weisburd - Cody W. Telep - Zoe Vitter - Trevor Bennett: Community-Oriented Policing to Reduce Crime, Disorder and Fear and Increase Satisfaction and Legitimacy Among Citizens: A Systematic Review. Journal of Experimental Criminology, vol. 10, 2014, pp. 399-428.

15 David Weisburd - Cody W. Telep - Joshua C. Hinkle - John E. Eck: Is Problem-Oriented Policing Effective in Reducing Crime and Disorder? Findings from a Campbell Systematic Review. Criminology \& Public Policy, vol. 9, no. 1, 2010, pp. 139-172.

16 Jerry H. Ratcliffe: Intelligence-Led Policing. Trends and Issues in Crime and Criminal Justice, no. 248,2003

17 Lawrence W. Sherman - David Weisburd: General Deterrent Effects of Police Patrol in Crime "Hot Spots”: A Randomized, Controlled Trial. Justice Quarterly, vol. 12, 1995, pp. 625-648.

18 Ronald J. Weitzer - Steven A. Tuch: Race and Policing in America: Conflict and Reform, Cambridge University Press, Cambridge, 2006 
si igazságosság alapfogalmából kiindulva kell megtenni, így a rendőri tevékenységet a következő kérdések szerint szükséges aposztrofálni:

- Mit csinál a rendörség és azt miért teszi?

- A rendőrségi müködésnek mi az eredménye?

- Milyen módon lehet a rendőri egyéni és a szervezeti müködés hibáit feltárni és artikulálni? Magyarán: van-e állampolgári hozzáférhetőséggel bíró normatív keretrendszer a rossz múködési effektusok visszajelzésére?

A legitim rendőri müködés záloga, hogy megfelelő mutatókat, indikátorokat alkossunk, és képesek legyünk a társadalmi müködések oldaláról pozitív hatásokat mérni kritikusan. Ami tehát a rendőri tevékenység legitimitását és a közvéleményt illeti, nemcsak annyit kell célul kitüznünk, hogy a statisztikai eredményességet javítva csökkentsük a büncselekmények számát, hanem egyúttal azt is, hogy megmutassuk az ahhoz vezető folyamatokat. A társadalmi „mellékhatásait” tekintve káros, azaz a többség által elutasított rendőrségi stratégia még a statisztikai eredmények javulása esetén sem kaphat igazolást és polgárjogot. A mellékhatásokat illetően az orvostudományi fogalom analógiája jól mutatja, hogy a komplex társadalom hasonlóképpen müködik, mint egy összetett élő organizmus. A mellékhatásokkal járó kezelések, gyógyszerek kísérleti tanulmányozása nélküli használata súlyos kockázatok forrása lehet. Gyakran kizárólag a mellékhatások mérésekkel tapasztalt fennállása dönt az ígéretesnek tünő eljárás elvetéséről. Mérés nélkül viszont nem beszélhetünk még a mellékhatás észlelésének esélyéről sem! Önmagában persze a mérés nem tünik jelentős „hír”-nek, a hiánya azonban annál inkább veszélyeket hordoz, ugyanis egy ,jó mérési” metódus nélkül rendkívül könynyen instabillá válhat a lakosság és a rendőrség viszonya, és akár egy rossz rendőri intézkedést vagy az informális viszonyokat szemléltető internetre feltöltött videó is erős közösségi reakciókhoz vezethet. Ha nincs jól és helyesen szemléltetve a rendörség és a politikai döntéshozók számára, hogy a közvélemény rendőrség iránti attitüdje ingatag és bizonytalan, akkor a pozitív objektív biztonsági helyzet eredményei pusztán csak félrevezetésre szolgálnak, és helytelen stratégiaformáláshoz vezetnek, ami konzerválja a feszültséget. A helyes és megfelelően megválasztott mérési eredmények ismerete csökkentheti a rendőri és politikai vezetők folyamatos frusztrációját a lappangó olyan kriminális incidensekkel kapcsolatban, amelyek hatására a szenzációhajhász média a lakosságot könnyen a rendörség ellen hangolja. 
Évek óta feladat a rendőrségi hatékonyság- és teljesítménymérés reformja, a tudományos terület jelentős eredményeket könyvelhet $\mathrm{el}^{19}$. A legtöbb erőfeszítés mégis a bünözés csökkentésére irányult, úgymint a felderítési ráta javítása, a letartóztatások számának növelése, a reakcióidő csökkentése stb. Az ezekre fókuszáló bünüldözési stratégia kudarcai hozták magukkal az irányváltást a lakossági bizalom és az elégedettség irányába történő kísérleti mérésekre. Áthelyeződött a mérés a közösségi rendfenntartás célját szolgáló multidimenzionális egységre, amely már csak részleges összefüggést mutat a rendőrség említett tényleges kimeneti teljesítményadataival, és egyre nagyobbat a közösségnek a helyben keletkező renddel kapcsolatos koncepciójával. Számos kutatás célozta meg a többrétű méréssel a társadalmi hatások és a legitim müködés lényegének megragadását, de ezek nem találtak széles körü elfogadottságra ${ }^{20}$.

A rendőrség multidimenzionális jelentőségének megismerése kapcsán a kutatók több lényeges adat hiányára hívták fel a figyelmet. Példának okáért egy olyan adatbázis kialakítására, amely országos szinten fedi le a rendőrség tagjaival kapcsolatos atrocitásokat. A 2004-es kutatási összefoglalóban már az amerikai Nemzeti Tudományos Akadémia is megfogalmazta igényét egy ilyen jellegü adatbázis felállítására. Ezek tartalmazhatnák a rendőri intézkedésekkel való szembeszegülés következtében keletkező testi sérüléseket vagy haláleseteket, esetleg a rendöröket ért támadásokat, illetve verbális inzultusokat, amelyek önmagukban nem keletkeztettek eljárásokat. Adatbázis hiányában néhány kutató saját kutatási adatbázis létrehozására tett kísérletet ${ }^{21}$. A rendörségi stratégiák negatív mellékhatásaival kapcsolatos szakmai diskurzusban számos javaslat született az Egyesült Államokban szö-

\footnotetext{
19 Edward R. Maguire: Measuring the Performance of Law Enforcement Agencies. CALEA Update, iss. 83, 2003. http://www.calea.org/calea-update-magazine/issue-83/measuring-performance-law-enforcement-agencies-part-1 of-2-oart-articl

20 Osnick Milligan - Lorie Fridell - Bruce Taylor: Implementing an Agency-Level Performance Measurement System: A Guide for Law Enforcement Executives. Police Executive Research Forum, Washington, D.C., June 2006; Mark H. Moore - Anthony A. Braga: Measuring and Improving Police Performance: The Lessons of Compstat and Its Progeny. Policing: An International Journal of Police Strategies \& Management, vol. 26, no. 3, 2003, pp. 439-453.; James J. Willis: Enhancing Police Legitimacy by Integrating Compstat and Community Policing. Policing: An International Journal of Police Strategies \& Management, vol. 34, no. 4, 2011, pp. 654-673.; Robert C. Davis: Selected International Best Practices in Police Performance Measurement. RAND Corporation, Santa Monica, 2012. http://www.rand.org/pubs/technical_reports/TR1153.html

21 Kyle Wagner: We're Compiling Every Police-Involved Shooting in America. Help Us. Regressing, blog post, 2014. http://regressing.deadspin.com/were-compiling-every-police-involved-shooting-inameric-1624180387
} 
vetségi szinten, ezek további jelentős információk megjelenítését célozták meg, egyebek között

- a rendőri erő alkalmazásának területi eloszlását az egész lakosságra vetítve, eszkalálódások helyszínei alapján;

- a panaszok nyomon követését;

- a rendőrök rendőri intézkedési kultúrával kapcsolatos véleményét és a közösség vélekedését ${ }^{22}$;

- rendőri aktivitások számát a közösség méretéhez, jellegéhez képest, a segélyhívások utáni rendőri intézkedéseket.

Tanulmányában Collier ${ }^{23}$ azzal a hipotézissel él, hogy az emberi jogoknak és általában a törvényes eljárásoknak árthat, ha a rendörök arra törekszenek, hogy megfeleljenek a teljesítménymérési céloknak. Arra következtet, hogy nagyobb autonómiát kellene helyi szinten adni, és elönyösebb lenne a minőséget mérő mutatókon nyugvó modell. A tanulmány vizsgálja, hogy a teljesítményorientált kultúra hogyan hat az emberi és garanciális jogokra, és a pénzközpontú indikátorok preferálása helyett javaslatot tesz egy a demokratikus alapjogokat értékelő és érvényre juttató teljesítménykultúra irányába történő elmozdulásra. Álláspontja szerint az emberi jogokkal kapcsolatos jogszabályokra azért kell kiemelt súlyt fektetni, mert azok a rendőri munka azon dimenzióiban kapnak hangsúlyt, ahol a rendőrnek bizonyos mozgástér adott a kötelességei teljesítésére. Lényegében az alapvető jogok garanciális fékező hatásának tulajdonítható, hogy a rendőri hatalom gyakorlása igazolódhat a szükségesség és az arányosság jegyében a letartóztatások, a körözések, a fogva tartás és bármilyen erőszak alkalmazási körében. Tanulmányukban Neyroud és Beckley ${ }^{24}$ a szakmai autonómia és a hatásosabb jogalkalmazói visszajelzés gyakorlatának növelését javasolják, ezek ugyanis nélkülözhetetlenek a rendőrségek fejlődése szempontjából a törvényes és garanciális jogok betartásának érdekében. Javaslatuk szerint a rendészeti teljesítménymérésben is be kell vezetni a ,professzionális klinikai modellt”. Ez a metódus az általános háziorvos tevékenységéhez hasonlítható, mivel a rendőr is belátása szerint oldja meg a problémákat, állítja fel a diagnózist, önállóan cselekszik és

22 Jack McDevitt - Chad Posick - Ruth Zschoche - Dennis P. Rosenbaum - Marc Buslik - Lorie Fridell: Police Integrity, Responsibility, and Discipline. National Police Research Platform, February 2011

23 Paul M. Collier: Police performance measurement and human rights. Public Money \& Management, vol. 21, no. 3, 2001, pp. 35-40.

24 Peter Neyroud - Alan Beckley: Policing, Ethics and Human Rights. Willan Publishing, Cullompton, 2000 
hoz döntéseket a rendelkezésre álló tények és körülmények ismeretében. Feilzer $^{25}$ az Angliában alkalmazott és lényegében kvantitatív forrású British Crime Survey (BCS) használatának veszélyeire figyelmeztet abban az esetben, ha azt a rendőri teljesítménymérés részévé kívánjuk tenni. Elsősorban módszertani kérdésekre fókuszál, különösképpen a mérési kérdések érvényességének, hatályosságának és validitásának hiányára. A dokumentum öszszefoglalja a BCS adatainak felhasználási hasznosságát a helyi rendőri erők teljesítményértékelésében.

Ahogy Moore és Braga $^{26}$ is rámutat: a rendőri szolgáltatások értékelése nemcsak egyszerüen azok által történik, akik személyesen igénybe veszik, vagy azzal érintkezésbe kerülnek, továbbá az értékelés sem csak addig tart, amíg azt igénybe veszik, vagy ameddig azzal kapcsolatba kerülnek, hanem az térben, személyben és időben is kiterjedtebb. Fontos, hogy a szolgáltatás a teljesítmény több különböző dimenzióját hordozza. A dimenziók sokféleségei föleg a társadalmi nézőpontok függvényében jelentkeznek. Abban a kérdésben a politikának kell megtalálnia a közös pontokat, és a sok nézöpont közül kiemelni az értékeket, amelyek közösek és egységesek az eltérő érdekek diverzitásában. Ezek szolgálhatnak alapul a rendőrség szervezeti teljesítményértékeléséhez, meghatározva ezzel alapvető küldetését. Az értékrend kiválasztásakor az értékelhető szempontok lehetnek anyagi vagy tárgyi jellegüek, olyanok, mint például a bünözés csökkenése, de támogathatja a szolgáltatások színvonalának növelését is. Ámbár utóbbinak olyannak kell lennie, amelyet a civilek elég fontosnak tartanak ahhoz, hogy az eljárásokban érvényre jussanak, és tisztességes eljárási kereteket teremtsen az elkövetők felderítéséhez és felelösségre vonásához.

A szerzők kifejtik, hogy messze áll a valóságtól az az érv, amely szerint a letartóztatások, elfogások, elővezetések számának növelésével lehet elérni a közösség érdekét szolgáló bűnözés csökkentését. Számos más olyan befolyásoló tényező létezik, amely a társadalomra nagyobb hatást kifejtve gyakorolhat a bünözés csökkenésére érdemi befolyást. Ilyen más tényezőnek tekinthető:

- a büncselekmények elkövetésének megelözése más eszközökkel, mint a letartóztatás és a személyi szabadság bárminemü korlátozása;

- az igazságszolgáltatás ne tévessze szem elől a korábbi elkövetőket;

\footnotetext{
25 Martina Y. Feilzer: Not fit for purpose! The (ab-)Use of the British Crime survey as a performance measure for individual police forces. Policing: A Journal of Policy and Practice, vol. 3, no. 2, 2009, pp. 200-211.

26 Mark H. Moore - Anthony A. Braga: Police performance measurement: A normative framework. Criminal Justice Ethics, vol. 23, no. 1, 2004, pp. 3-19.
} 
- a félelemérzet mérséklése, a biztonság megteremtésének előmozdítása;

- a bünözés terheinek csökkentése érdekében a közösség ösztönzése a társadalmi részvétel érdekében;

- a közúti forgalom és közösségi terek használatában érdekeltté tenni a közösséget a biztonság és a rend megteremtésével, és az erőforrások egyenlő használatával;

- a különböző orvosi és szociális szolgáltatások igénybevételének támogatása.

Ezen túlmenően, a végső értéket nemcsak e hatások a rendőrség által előállított „termékek" pozitív eredménye határozza meg, hanem az is, hogy a felmerülő költségekhez a társadalom maga is érdemben hozzájárult. A költségeken így nemcsak a konkrét pénzösszeget értjük, amelyet a rendőri szolgáltatásokra költünk, hanem a szabadság és a magánélet bizonyos elemeiről való lemondás értékét is, amellyel megvédhető a társadalom a bünözéstől. A rendészet autoritása és hatalmi mezőjének szélesedése egyenesen arányos a költségvetési kiadás növekedésével. Ideális esetben tehát úgy szeretnénk elöállítani a rendészet öszszes értékes eredményét, hogy ahhoz minél kevesebb közpénzt használunk fel, és minél kevesebb hatósági jogkört társítunk. A társadalom egyszerre várja el a hatalmi tényező csökkenését és a kiadások visszaszorítását.

Gondolati modelljükben megkülönböztetnek haszonelvü és értékalapú elveket. Természetesen, az egyének és a közösségek gyakran szeretnék az elvi értékeket is a gyakorlati értékekhez hasonló értékelés alá vetni. Különösen igaz ez akkor, amikor egy hatósági feladatokat ellátó szerveződésről van szó, ilyenkor tudni szeretnék, hogy mennyi pénzt költ el az állam a kitüzött elvi szintü közösségi célokra. Az is igaz, hogy ezek a célkitüzések értékes gyakorlati eredmények formájában jelennek meg. A büncselekményeket csökkenteni azonban az elrettentés és a szabadságkorlátozás által is lehet, amely az eredményt a minél több elkövető elfogásában jelöli meg. A szabályok betartása ellenben lehet megbízhatóbb és költségkímélőbb, ha a polgárok úgy vélik, hogy a rendszer, amely kikényszeríti a szabályok betartását, egyben legitim és széleskörüen elfogadott. Nyilvánvaló, hogy feszültséget kelthet, ha a biztonság fokozása érdekében történő intézkedések összeütköznek a polgárok szabadságjogaival és az emberi jogokkal. Ámde a lényeg az, hogy ezeket az elvi értékeket meg kell különböztetni a haszonelvü értékektöl, és szintén fontos értékek a közösségi rendőri tevékenység értékelésénél. ${ }^{27}$

27 Mark H. Moore - Anthony A. Braga (2004): i. m. 
Tanulmányukban Charbonneau és Riccucci ${ }^{28}$ vázolják a társadalmi egyenlőség tényezőinek fontosságát. Ennek során társadalmiegyenlőség-indikátorokat javasolnak, ideértve a fair bánásmód értékelését, ami hasonló ahhoz, amit egyébiránt „eljárási igazságosságként” is definiálni szoktak. Álláspontjuk szerint ezeket tartalmaznia kellene a rendőrségi teljesítmény és hatékonyság mérésének, ugyanis ezek szoros kapcsolatban állnak a közösségi rendörségi munkával. Elemzést nyújtanak az empirikus és elméleti kutatások hatásairól és eredményeiről a rendőrség teljesítménymérésének területén. Az elsődleges céljuk annak megállapítása, hogy milyen mértékben függ össze a társadalmi egyenlőtlenség a rendőrségi teljesítményt mérő mutatókkal. A szerzők szakirodalmi következtetése az, hogy a társadalmi különbségek mutatói létezők, de azok továbbra is marginális szerepet töltenek be a különböző rendőrségek teljesítményértékelésekor. Mindez annak ellenére megállapítható, hogy a társadalmi különbözőségek a „teljesítményintézkedések” hatékonysága szempontjából kiemelkedő jelentőségüek. Végső konklúziójuk, hogy súlyos következményekkel járhat, ha a hatékonyság - különösen a rendőrség esetében - nem támaszkodik a szociodemográfiai tényezőkre.

Kétségtelen, hogy a hatékonyság többet jelent, mint az eredményesség, vagyis a szolgáltatás minőségével együtt azt is, hogy a szolgáltatás eléri-e célját, és kielégíti-e az adott közösség igényeit ${ }^{29}$. A hatékonyságot az eredményesség kontextusában vizsgálva kiderült, hogy az egyik fejlesztése a másik rovására mehet ${ }^{30}$. A hatékonyságmérés elemei közé tartozik például a bünözés mértéke, a letartóztatások száma, a nyomozáseredményességi mutatók, így a teljesítményre vonatkozó intézkedések hatékonyságához tartozó mutató a letartóztatások és rendőrök aránya, és a rendőrségi járművek használatának fajlagos költsége. Mindamellett egyre nagyobb lett a tudományos aggodalom, amely szerint ezek az indikátorok háttérbe szorítják az olyan demokratikus és alkotmányos értékeket, mint amilyen a méltányos és tisztességes eljárás, és az egyenlő bánásmód, amelyek pedig a rendőri eljárások középpontjában vannak ${ }^{31}$.

28 Étienne Charbonneau - Norma M. Riccucci: Beyond the usual suspects: An analysis of the performance measurement literature on social equity indicators in policing. Public Performance and Management Review, vol. 31, no. 4, 2008, pp. 604-620.

29 Harry P. Hatry: Performance measurement: Getting results. 2nd ed. Urban Institute Press, Washington, D.C., 2006

30 Gloria A. Grizzle: Performance measurement and dysfunction: The dark side of quantifying work. Public Performance \& Management Review, vol. 25, no. 4, 2002, pp. 363-369.

31 James R. Brunet: Measuring social equity performance in the criminal justice system. Paper presented at the Fifth Social Equity Leadership Conference, Omaha, 2006 


\section{A rendőrség hatékonyságmérésének gyakorlata Angliában és Walesben, különös tekintettel a legitim múködés jellemzőire}

A brit kormány 2005-ben a rendőri tevékenység mérésével ugyancsak ambiciózus célt tüzött ki, hogy javulást tudjon elérni. Egy új rendszert vezettek be, a rendőrség teljesítményértékelési keretrendszerét (Police Performance Assessment Framework; PPAF), amely hat, a British Crime Survey-böl leválogatott statisztikai alapú teljesítménymérés adatai alapján határozta meg a teljesítményt. Ezt a hat BCS-mutatót fel lehet osztani az azonnali rendőri intézkedések és az áldozattá válás kockázati számaira. A vizsgálat alapját a BCS-adatok másodlagos elemzése adta, amely két aspektusból vizsgálta az adatokat, egyrészt a rendőrségnek a tudomásra kerülés körüli intézkedései, másrészt a bünözés becslése oldaláról. Feilzer megvizsgálta a 2006-2007-ből származó adatokat a helyi rendőrség szemszögéből, és arra a következtetésre jutott, hogy az azonnali intézkedéseket tartalmazó BCS használata a teljesítménymérésnél érvénytelen, kontextusfüggő, és erősen összefügg a gazdasági-demográfiai viszonyokkal, így alapvetően megbízhatatlan. ${ }^{32} \mathrm{~A}$ teljesítménymérés rendszere, mérete és metódusa jól mutatta, hogy válhattak éppen a helyi rendőrségek leginkább reaktívvá.

A rendőrség iránti bizalom leginkább a rendőri magatartás és az eljárások törvényességében és igazságosságában jelenik meg, föként olyan indikátorokban, mint amilyen a tisztesség, a felelősség, a tisztelet és az egyenlöség. Mindezek konkrét egyedi döntésekben megmutatkozó olyan elveket takarnak a rendészetben, amik a rendöri funkció zálogaiként nem könnyen mérhetők, és föleg nem rövid távon, de hosszú távon mégis nagyobb hatással vannak a közbizalomra, mint bármilyen rendőrségi PR-tevékenység. Negatív tendenciaként a szakma követte a politika folyton változó szeszélyét, megszállottan szolgálva a változtatásokat a közszolgáltatások színvonalának javítására anélkül, hogy elég időt adtak volna arra, hogy meggyőződjenek arról, ezek a változások valóban a helyi rendőri erők teljesítményének nagyobb hasznosulását szolgálják.

Az eredményesség (effectivness), hatékonyság (efficiency) és a legitim müködés (legitimacy) mindhárom szegmensét felölelő hatékonyságmérési metódus jelenleg egyedül Angliában és Walesben müködik. A rendőrség teljesítményértékelési mutatói a társadalom számára nyilvánosak, bárki által hozzáférhetők. Ez messzemenőkig támogatja a rendőrség müködéséhez szükséges állampolgá-

32 Martina Y. Feilzer: i. m. 
ri bizalom legfőbb forrását jelentő átláthatóságot. Az értékelési rendszer három pillérből áll. Az első az eredményességet megtestesítő adatok köre, ami a rendőrség müködésével összefüggésben keletkező nagyrészt kvantitatív statisztikai adatból képződik, és ami többségében a lakosságszámra, de szigorúan a rendőri egységekre van vetítve, ez nemcsak a bünözéskontroll ellátása során keletkezett adatokat, hanem a szolgáltatásközpontú bünmegelőzési tevékenységet is számszerüsíti. A második pillér a pénzügyi hatékonyság: mennyibe is kerülnek ezek a rendőri szolgáltatások a lakosságnak, így költség tekintetében mennyire hatékony az adott rendőri egység. A harmadik pedig a legitimitás, e fogalom lefedi a lakosság bizalmát, elégedettségét és az ennek forrását jelentő társadalmi egyenlöséget. A konkrét rendőri szerv teljesítményének értékelésére e három pillér összevetésével egy négyfokozatú skálán kerül sor.

\section{Az eredményesség indikátorai}

Az eredményesség megállapítása Angliában és Walesben a következö tényezők alapján történik:

- segélyhívások száma, amely adatokat ezer lakosra vetítve és tizenkét hónap átlagában tüntetik fel;

- regisztrált büncselekmények száma a csalás kivételével, ezer före és tizenkét hónapra vonatkozó adatok alapján, aktuális adatokkal, és azok tizenkét hónapos, illetve ötéves változásában;

- elítélések aránya (vádemelések száma);

- azoknak az eseteknek az aránya, amelyekben megállapították az elkövető személyét, de a sértetti közremüködés hiánya miatt nem volt lehetséges a bizonyítás;

- negatív felderítési mutató, vagyis az elkövető tekintetében sikertelen nyomozások száma;

- külön a közterületi rendbontások (antiszociális incidensek), büncselekmények, szabálysértések száma, szintén egy év alatt ezer före számolva;

- a tizenkét hónapon belül ezer főre jutó családon belüli erőszak aránya;

- családon belüli erőszak arányának változása tizenkét és huszonnégy hónap arányában az összes büncselekményen belül;

- egymillió före számolva hány szervezett bünözői csoport beazonosítására kerül sor az adott időszakban;

- sértetti elégedettség aránya tizenkét hónap alatt. 
Az éves jelentés táblázatban ábrázolja az összesített adatokat, illetve külön minden adat vonatkozásában az egyes megyei rendőri egységeket teljesítményük alapján. Külön szerepel még az ezer főre jutó rendőri létszám és a csalások regisztrált száma is. A jelentés végén a következők alapján minősítik a rendőri egységeket:

- a büncselekmények megelözése;

- sebezhetőség (különleges bánásmódot igénylö sértetti kör);

- nyomozások eredményessége, támogatása;

- súlyos és szervezett büncselekmények köre.

A megelőzéshez tartozik egyebek között:

- a szomszédsági rendőri modell müködtetésének aránya;

- a közösségi médiák müködtetése az adott rendőri egységnél, figyelemmel arra, mennyire használt és elterjedt a helyi lakosság körében (kommunikációs felületeken történő üzenetek forgalma alapján);

- a közösségi (szomszédsági) rendőrök számának és igénybevételének változása;

- a lakossági bejelentés alapján regisztrált közterületi büncselekmények aránya, azok változása;

- az ilyen büncselekményi körben az ismételt áldozattá válás aránya ezer före és tizenkét hónap átlagára vetítve.

A nyomozáshoz kapcsolódó indikátorok:

- az ezer lakosra jutó nyomozással foglalkozó rendőrök száma tizenkét hónap átlagában;

- csalásokban indított nyomozások átadása, mert a gazdasági bünözést külön kezelik;

- az egyes nyomozásokat különválasztják a bonyolultságuk és kárértékük szerint, így megkülönböztetnek helyi nyomozásokat, és bonyolultabb nyomozástípusokat;

- az állomány körében végzett felmérés alapján a nyomozásokra fordított időkeret és a tényleges munkaidő egymáshoz viszonyított aránya;

- a digitális eszközök használatának változása a nyomozások során (növekedés);

- az akták vezetői ellenőrzése számában bekövetkezett változások;

- a digitális kriminalisztikai eszköztár kihasználtsága, igénybevétele egyes kapitányságokra bontva; 
- a sértett által nem támogatott nyomozások aránya, így a bizonyítás nem volt lehetséges, ami azért lényeges, mert jól utal a rendőrség iránti bizalom csökkenésére, nem sikerül meggyőzni arról, hogy megkapja a megfelelö védelmet és az igazságszolgáltatás is az ő érdekei szerint fog eljárni;

- a gyanúsítottak száma ezer főre vetítve és tizenkét hónap átlagában;

- az ezer före jutó körözöttek száma, tizenkét hónap átlagában;

- a kiadott körözések idejének átlaga;

- az egy év alatt, száz büncselekményre jutó letartóztatások száma rendőri egységenként;

- a szexuális jellegü jogsértések miatti bejelentések során a ténylegesen szexuális büncselekmények miatt megindított eljárások aránya.

Sebezhetőség (sértetti kör tekintetében speciális eljárás, hozzáállás) szempontjából (ez hazai viszonylatban a különös bánásmódot igénylő sértett kategóriájának felel meg) és az életkorral és a támadás elhárításra való alkalmasságával leginkább összefüggésben, a következő indikátorokat határozták meg:

- az azonosított áldozatok aránya kapitányságonként, egy év átlagában;

- ennek változása tizenkét hónap átlagában;

- kapitányságonként a száz családon belüli erőszakra jutó családon belüli erőszak miatti letartóztatások száma, tizenkét hónap átlagában;

- nyomozások eredményessége, a parancsnoki ellenőrzés sikeressége, és az áldozati elégedettség aránya a családon belüli erőszak körében;

- az áldozatok nem támogatása miatt meghiúsuló nyomozás aránya az összes efféle ügyre vetítve.

A súlyos és szervezett büncselekmények köréhez tartoznak a következő indikátorok:

- a feltérképezett szervezett bünözői körök száma rendőri egységenként, tizenkét hónapra vetítve;

- ugyanennek a változása százalékban egy évre visszamenően;

- támogató hatások, amelyek jótékonyan hatnak a szervezett bünözésre (új metódus), ezek pozitív aránya rendöri egységenként, száz szervezett bűnözői körre vetítve;

- utcai bünbandák rendőri egységenként, tizenkét hónapot tekintve;

- száz esetre jutó tanúvédelmi program alkalmazása. 


\section{A hatékonyság indikátorai}

Általános költséghatékonysági adatként minden évben közlik a következőket: - a teljes költségvetés, előirányzattal, változásokkal, megtakarítás-elörejelzéssel, illetve utóbbi teljes költségvetéshez viszonyított arányával;

- a tervezett személyügyi kiadások és teljes kiadások, az ezekhez képest történő eltérések aránya;

- ezer lakosra vetített kiadás (személyügyi, teljes) tizenkét hónapra vetítve.

Külön megjelenítik és összehasonlítják mind a negyvenhárom rendőri egység pénzügyi gazdálkodását a megtakarítások és a kiadások terén. Továbbá látható, hogy ezer lakosra vetítve mekkora a rendőri munkaerő aránya, és ez hogyan változott az utóbbi öt évben, helyben és nemzeti átlagban. Az áldozattá válási mutató és annak ötéves változása szintén jól nyomon követhetö helyi és nemzeti viszonylatban. A hatékonyság alapján mindenki számára világossá válhat, hogy a rendörség müködése mennyibe kerül, így reálisan felmérhetö, hogy a szolgáltatás milyen költségekkel jár. Ez az adat különösen előnyös lenne Magyarországon, hiszen a közbeszédben rendkívül általánosító és pejoratív éllel van jelen a rendőrség ,adókból” finanszírozott minősége, ami ha konkrét, érthető adatokkal, transzparens módon jelenne meg, akkor az állampolgárok számára helyben és országos viszonylatban is pontosan érthetövé tenné, milyen költségekért milyen szolgáltatásokat kapnak. A teljesítménymérésnek ez mindennél fontosabb célja.

\section{A legitimitás indikátorai}

Anglia és Wales rendőrsége a transzparens teljesítményadatok részévé teszi a legitim müködést, és deklarálja, hogy a méltányos és tisztességes bánásmód központi eleme a teljes rendőri gárdának, ebből a célból a nyilvánosság és a független tanácsadók, vagyis a civil részvétel fejlesztése mellett tör lándzsát. Kommunikációs visszajelző csatornákat müködtet, továbbá segíti a szoros együttmüködést, elsősorban a hatalommal való visszaélés és a korrupció elkerülésének céljából. Folyamatosan vizsgálja a vezetői és beosztotti szinteket annak érdekében, hogy feltérképezze és kiszürje a tisztességes és méltányos eljárásokat sértő komponenseket, sokrétü tanácsadó és tájékoztató lehetőséget kínál az állampolgári vélemények begyüjtéséhez és értékeléséhez. Elismerik és alkalmazzák azt a tudományos tényt, hogy az egyes eljárásokban és 
az intézkedésben nagyobb mértékben érvényesített tisztességes és méltányos bánásmód jelentős hatással van a büncselekmények felderítési és a megelözési hatékonyságára ${ }^{33}$. Azt, hogy mi tekinthető etikus eljárásnak, az Egyesült Királyság rendőrségének etikai kódexe határozza meg $^{34}$. Sajnos a közvélemény-kutatások és a felmérések azt mutatják, hogy a színes bőrüek, ázsiaiak és más kisebbségek szerint a rendőrség egyre kevésbé bánik egyenlő módon az emberekkel ${ }^{35}$.

A lakosság körében a legitimitás kérdését illető felmérés eredményét független szervezetek szavatolják. 2016-ban a megkérdezettek ötvenhat százaléka mondta azt, hogy a rendőrség tisztességesen és egyenlően bánik az állampolgárokkal, hét százalék szerint ez egyáltalán nincs így, míg harmincnyolc százalék szerint romlott a rendőrök hozzáállása. Minden rendőri egységhez kapcsolódnak független tanácsadó szervezetek, amelyek akár bejelentés nélkül beléphetnek a rendőrségi fogdákba és előállítóhelyiségekbe, megvizsgálhatják a fogva tartás körülményeit, beszélhetnek a fogvatartottakkal és az eljárás alá vontakkal. Erről éves jelentés készül, ami szintén mutatója a legitimitás pillérének.

A legitim müködés nemcsak a közösség irányába jelenik meg etikus, tisztességes és korrekt feladatvégzés sajátos karakterjegyként, hanem meghatározó jelentőséggel bír a szervezeti kultúrát érintően is. A szervezet vezetésének a dolgozókhoz való hozzáállása, tisztelete, az elismerési és előmeneteli rendszer müködtetése, a „házon” belüli sérelmek miatti panaszok kezelése és az egyéni és rendszertermészetű anomáliák döntően meghatározzák a rendőrség közösség irányába megnyilvánuló intézkedési, viselkedési morálját, attitüdjét ${ }^{36}$. Széles körü, átfogó kutatást végeztek a rendőri állomány vonatkozásában, amely igazolta, hogy a szervezeten belüli egyenlö és tisztességes bánásmód óriási hatást gyakorol az alkalmazottak intézkedési kultúrájára ${ }^{37}$.

33 Andy Myhill - Paul Quinton: It's a fair cop? Police legitimacy, public cooperation, and crime reduction. An Interpretative Evidence Commentary. National Policing Improvement Agency, 2011. http://whatworks.college.police.uk/Research/Documents/Fair_Cop_Briefing_Note.pdf

34 Code of Ethics: A Code of Practice for the Principles and Standards of Professional Behaviour for the Policing Profession of England and Wales. College of Policing, July 2014. www.college.police.uk/What-we-do/Ethics/Documents/Code_of_Ethics.pdf

35 Crime statistics, focus on public perceptions of crime and the police, and the personal well-being of victims. Office of National Statistics, March 2015

36 Fair cop 2: Organisational justice, behaviour and ethical policing. College of Policing, 2015. http://whatworks.college.police.uk/Research/Documents/150317_Fair_cop\%202_FINAL_REPORT.pdf

37 Tom R. Tyler - Steven Blader: Cooperation in groups: Procedural justice, social identity, and behavioral engagement. Psychology Press, 2000; Jason A. Colquitt et al.: Justice at the millennium: A metaanalytic review of 25 years of organizational justice research. Journal of Applied Psychology, vol. 86, 2001, pp. 425-445. 
Egyes tanulmányok fordított előjelű összefüggést mutattak ki a rendőri szolidaritás, a saját maguk által elkövetett törvénytelenségek és a külvilág irányába történő orientáció között $t^{38}$. Aligha lehet kétséges, hogy egy ellenséges, oppozícióban lévő társadalmi közegben minden kívülálló és feladatait tekintve visszatetszést keltő csoport a saját értékeibe és kohéziójába kapaszkodva igyekszik fenntartani a védekezőképességét ${ }^{39}$. Ennek következménye az ellenséges környezeti tényezők további erősödése vagy reprodukciója ${ }^{40}$, amikor már teljesen felesleges a hibákat vagy okokat firtatni, különösen, ha azok hosszú ideje beágyazott kollektív társadalmi vagy szubkulturális negatív sztereotípiával párosulnak. A japán rendőrségi modell hatékonysága igazolta, hogy a belcsoportok befelé irányuló tisztelete, elfogadása, megbecsülése, és a csoport összetartozását erösítő értékeinek és hagyományainak pozitív elfogadására épülő intenzív identifikáció egyenesen arányos a kifelé irányuló orientáció növelésének szükségletével ${ }^{41}$. Következésképpen, ha a rendőrség öszszetartozás-igényét nem a társadalom intoleranciával szembeni védekező attitüdje alakítja ki, akkor normál esetben ez a kohézió pozitívan hat akár a rendőrség társadalmi beágyazódására is. Finszter Géza szerint a rendszer oktalan titkolózása okozza a társadalom rendőrség iránti elöítéletességét, amelyre a testület tagja maga is elöítélettel válaszol ${ }^{42}$.

Éppen erre alapozva kulcsterület a rendőri munka támogatása és a teljesítménymotiváció növelése. Az állomány döntéshozatali folyamatokba történő bevonása, az, hogy meghallgatják az aggályaikat, miközben átláthatóvá válik, hogy vezetők miért jutottak bizonyos döntésekre, kétségtelenül pozitívan hat a saját munkájuk korrekt és tisztességes végzésére ${ }^{43}$. A szervezeti igazságosság kérdése tágabb kört ölel fel, mint az eljárási igazságosság, magában foglalja a disztribúció igazságosságát, vagyis annak érzetét, hogy a forrásokat, a munkaerőt, az anyagi és szellemi dotációt mennyire tisztességesen osztják el a szervezeten belül. A proceduális igazság az előbb említett részvétel mellett magában foglalja a döntésekről való értesülést és a vezetők beosz-

\footnotetext{
38 Stan K. Schernock: An empirical examination of the relationship between police solidarity and community orientation. Journal of Police Science and Administration, vol. 16, 1988, pp. 182-194.

39 Douglas W. Perez: Common Sence about Police Review. Temple University Press, Philadelphia, 1994 40 Fogarasi Mihály: A rendőrség és a társadalom. In: Fogarasi Mihály (szerk.): Pszichológia rendőri vezetőknek. Rendőrtiszti Főiskola, Budapest, 2003

41 Kenneth L. Dion: Intergroup conflict and intragroup cohesiveness. In: William G. Austin - Stephen Worshel (eds.): The social psychology of intergroup conflict. Brooks/Cole, Monterey, 1979, pp. 221224.

42 Finszter Géza: A rendészet rendszerszemléletű megközelítése és a stratégiai tervezés. Tanulmányok a rendészeti stratégiához. Rendészeti Szemle Különszám, 2010

43 Fair cop 2... i. m.
} 
tottakkal való tisztességes és emberséges bánásmódját. A kettő közül a környezetre irányuló viselkedésmódra történő hatás oldaláról a procedurális igazságot tartják erősebbnek ${ }^{44}$.

A durhami rendőrségen végzett oxfordi kutatás meggyőző érvként szolgált arra, hogy a szervezeti igazságosság, ami felöleli a vezetők és a felső vezetők eljárási igazságosságát (döntéshozatalba bevonás, értesítés, bánásmód), illetve az említett elosztási igazságosságot, pozitív hatást gyakorol a szervezeti összetartozásra és a szociálisabb, kooperatívabb szervezeti attitüdre és viselkedésformákra, amelyek azután befolyásolják a beosztottak munkakultúráját ${ }^{45}$.

Statisztikailag szignifikáns összefüggést talált egy másik kutatás is a szervezeti igazságosság és a szervezettel való azonosulás között a rendőrségnél, ami ténylegesen kihat a szervezeti eredményességre:

- Azok a tisztek, akik felismerték, hogy a szervezet tisztességes, sokkal nagyobb valószínüséggel azonosultak a szervezettel.

- A tisztességtelenség következetesen összefügg a tisztek cinizmusával és önkényuralmi szubkultúrájának kialakulásával.

- Azok a tisztek, akik úgy érezték, hogy a közösség támogatását élvezik, jobban bíztak saját hatóságukban.

- Azok a tisztek, akik jobban bíztak a saját szervezetükben, jobban támogatták az eljárásjogi garanciákat és a törvényes eljárásokat, valamint az arányos erő alkalmazását. ${ }^{46}$

A méltánytalanság és a szervezeti igazságosság hiánya a rendőrségen jelentős szervezeti kockázat. A kutatások eredményei arra utalnak, hogy ha a beosztottak úgy érzik, hogy igazságtalanul bánnak velük, nagy valószínüséggel kevésbé éreznek késztetést arra, hogy minőségi szolgáltatást nyújtsanak a lakosságnak. Egyre cinikusabbá válnak, és kevésbé lesznek elkötelezettek az etikus rendfenntartás ügyében. Más munkahelyeken végzett kutatások arra utalnak, hogy a gyenge szervezeti igazságosság jótékonyan hat a dolgozói

\footnotetext{
44 Jerald Greenberg: Organizational justice: The dynamics of fairness in the workplace. In: Sheldon Zedeck (ed.): APA handbook of industrial and organizational psychology, vol. 3: Maintaining, expanding, and contracting the organization. American Psychological Association, Washington, D.C., 2011

45 Ben Bradford - Paul Quinton: Self-legitimacy, police culture and support for democratic policing in an English constabulary. British Journal of Criminology, vol. 54, no. 6, 2014, pp. 1023-1046.

46 Ben Bradford - Paul Quinton - Andy Myhill - Gillian Porter: Why do 'the law' comply? Procedural justice, group identification and officer motivation in police organizations. European Journal of Criminology, vol. 11, 2013, pp. 110-131.
} 
megbetegedések mértékére és a munkavállalói lopásokra. Gondoskodni kell arról, hogy a vezetési gyakorlat tisztességes, befogadó és nyitott legyen, törekedni kell arra, hogy folyamatos monitorozással felszínre kerüljenek a szervezetet érintő rendellenességek. Az etikus, legitim rendőri müködés tehát szoros kontextusban van a szervezeti kultúrával, a belső eljárási igazságosság érvényesülésével. Ezeket lényegében „visszacsatolási hurkoknak” nevezzük, vagyis a procedurális igazság szervezeten belül nagyobb társadalmi támogatottságot hordoz, ellenben ezek negatív vonatkozásban is megjelenhetnek, visszahatva a szervezeti teljesítményre. Mindezeket a kutatási eredményeket szem előtt tartva végeznek - a hatékonyságmérés részeként - minden évben a legitimitást érintő kutatásokat. 2015-2016-ban tizenhat rendőri egységnél került erre sor. Roadshow-k, online blogok, beszélgetőfórumok segítik, hogy azonosítani lehessen a szervezeten belüli tisztességtelen gyakorlatokat, állapotokat. Az állomány tagjait érő sérelmekre, panaszokra müködtetnek egy eljárási rendet, ennek alapján rendszerezhetők az adatok, és összehasonlíthatók a rendőri egységek.

Anglia és Wales rendőrsége büszkélkedhet a rendőrség teljesítmény- és hatékonyságmérése tekintetében a legbőségesebb tudományos irodalommal, kutatási elméleti bázissal Európában. Ráadásul az elméleti kutatási eredményeket viszonylag gyorsan beépítik a gyakorlatba.

\section{Megállapítások, következtetések}

A statisztikai szemlélet okozta hatékonysági problémakör alapvetően a rendőrség egzakt statisztikai mutatóinak látható megjelenítési kényszerével magyarázható ${ }^{47}$. Így a számok mögött rejtőző tényleges és valódi munkateljesítmény és minőség háttérbe szorul, ami elismerés hiányában fejlődésre sem ösztönöz. A jelenlegi hazai rendörségi teljesítménymérési modell nagyrészt ügyeredményességi bázisú, vagyis mennyiségre kalibrált. Így nem elégíti ki a költséghatékonyság és a legitim müködés, tehát az olcsóság és a „minőség” prezentálásával kapcsolatos lakossági és tudományos igényeket sem. A világ azonban az utóbbi évtizedekben nagyot változott, egy információs társadalomban már nem a statisztikai eredményességről kell hogy szóljon a rendőrség munkája. Hanem arról, hogy minél hitelesebben állapítsuk meg, milyen

47 Krémer Ferenc - Molnár Emília: Modernizálható-e a magyar rendőrség? A rendőrök véleménye. Magyar Rendészet, 2000/3-4., 82-102. o. 
valós társadalmi hatásokat váltott ki a tevékenységünk (mekkora elégedettséget, bizalmat, elismerést vívott ki a társadalomban). A közösségi appercepció és a rendőrségi hatékonyságmérés eredményeit összhangba kell hozni úgy, hogy a szubjektív érzületet befolyásoló összes tényezőt fel kell térképezni és meg kell érteni. Kutatásokkal elsődlegesen azt kell kideríteni, hogy milyen tényezők befolyásolják az egyének rendőrség iránti bizalmát és támogató hozzáállását. Ma már bármilyen információtartalom pillanatok alatt elérhető a világhálón, ahonnan kedvünknek megfelelő szélességü és mélységü tájékoztatáshoz, hírekhez juthatunk. A változás tétje a politika oldaláról sem jelentéktelen: az azonnali hírmegosztás lehetősége pillanatok alatt tektonikus társadalmi hatásokat generálhat. Egy a társadalmi szerepét tekintve magát tévesen pozicionáló, eredményei tekintetében önigazoló rendőri szervezet puskaporos hordón ül. Ebből is fakadhat a modern demokráciák kormányzatainak fokozódó igénye, hogy a rendőri müködés tényleges társadalmi hatásait tudományos igényességgel térképezzék fel. 